\title{
MORBIDITY AND MORTALITY AMONG ROAD USERS IN BENIN-CITY, NIGERIA
}

\author{
${ }^{1}$ M. A. Nzegwu, ${ }^{2}$ A. A. F. Banjo, ${ }^{3}$ W. Akhiwu, ${ }^{1}$ J. U. Aligbe and ${ }^{4}$ C. O. Nzegwu \\ ${ }^{1}$ Department of Morbid Anatomy, University of Benin Teaching Hospital, Benin City Edo State Nigeria \\ ${ }^{2}$ Department of Pathology, College of Medicine, University of Lagos, Lagos, Nigeria \\ ${ }^{3}$ Nigeria Police, Benin City, Nigeria \\ ${ }^{4}$ Grace Eye Clinic, Benin City, Nigeria \\ Reprint requests to: Dr. M. A. Nzegwu, Department of Morbid Anatomy University of Nigeria Teaching Hospital, \\ P. M. B. 01125 Enugu. Enugu State .Nigeria. \\ E-mail: martin nze@yahoo.co, Tel.: +234-0805-5509566
}

\begin{abstract}
Background/objective: Murray and Krug had reported that road traffic injuries are a major cause of death globally, with disproportionate number occurring in developing counties. Seventy out of 308 deaths that occurred in Benin City from August 2002-July 2003, representing $22.7 \%$ of all deaths was due to road traffic injuries. Despite this observation, there is a paucity of data on road traffic morbidity and mortality. The aim of this study was to evaluate patterns of morbidity and mortality among drivers and passengers of cars involved in road traffic accidents in Benin-City Nigeria from August 2002-July 2003 as a base line data.

Methods: Eighty-seven car drivers and passengers who were studied were part of a larger study, involved in a road traffic accident and brought to the accident and emergency units of either the University of Benin Teaching Hospital or the State Specialist Hospital between August 2002July2003. The injured ones were examined and dead patients had autopsy done on them.

Results: Over all, out of 283 total accidents cases reviewed in the period of study 87 were car occupants representing $30.7 \%$ of all accident cases, and 67 patients $(23.7 \%)$ sustained varying injuries, while 20 patients $(7.1 \%)$ died. Commercial cars were involved in majority of cases $85 \%$. Males were also more in number. Intracranial hemorrhage was the predominant cause of death.

Conclusion: Occupants of cars accounted for the singular most common category of morbidity and mortality among all road users. The male to female ratio was 2.1:1. Windscreen injuries most commonly associated with facial and head injuries represented the commonest cause of morbidity and mortality. The commonest autopsy finding as cause of death was intra-cranial hemorrhage.
\end{abstract}

Key words: Road traffic accident, morbidity, and mortality, car-Occupants, wind screen

\begin{abstract}
Résumé
Contexte/Objectif: Murray et Krug avaient rapporté cela rles dommages du trafic d'oad sont une cause importante de la mort globalement, avec le nombre disproportionné se produisant dans les comtés se développants. Soixante-dix sur les 308 décès qui se sont produites dans la ville du Bénin d'août 2002 à juillet 2003, représentant $22.7 \%$ de toutes les décès étaient dus aux dommages du trafic de route. En dépit de cette observation, il y a un manque des données sur la morbidité et la mortalité du trafic de route. Le but de cette étude est 1 . Pour évaluer des modèles de la morbidité et de la mortalité parmi des conducteurs et des passagers des voitures impliquées dans des accidents de trafic de route dans la Bénin-Ville Nigéria de Août 2002 à juillet 2003 comme grande ligne données.
\end{abstract}


Méthodes: Les conducteurs et les passagers de voiture d'Eighty-seven qui ont été étudiés faisaient partie de une plus grande étude, impliqué dans un accident de trafic de route et apporté aux unités d'accidents et de secours de l'université de l'hôpital de enseignement du Bénin ou de l'hôpital de spécialiste en état entre l'août 2002 à juillet 2003. Blessés ont été examinés et les patients morts ont eu autopsie faite sur eux.

Résultats: Au-dessus de tous, sur 283 cas totaux d'accidents passés en revue dans la période de l'étude 87 étaient des occupants de voiture représentant $30.7 \%$ de tous les cas d'accidents, et 67 patients (23.7\%) ont soutenu des dommages variables, alors que 20 patients $(7.1 \%)$ mouraient. Des voitures commerciales ont été impliquées dans la majorité d'affaires $85 \%$. Les mâles étaient également plus en nombre. L'hémorragie intra-crânienne était la cause prédominante de la mort.

Conclusion: Les occupants des voitures ont expliqué le singulier la plupart de catégorie commune de morbidité et mortalité parmi tous les utilisateurs de route. Le mâle au rapport femelle était 2.1:1. Dommages de pare-brise le plus généralement associés aux dommages faciaux et principaux a représenté la cause la plus commune de la morbidité et de la mortalité. L'autopsie la plus commune trouvant comme cause de la mort était hémorragie intra-crânienne.

Mots clés: Accident de trafic de route, morbidité, et mortalité, occupants de voiture, écran de vent

\section{Introduction}

Road traffic injuries are a major cause of death globally, with disproportionate number occurring in developing counties. ${ }^{1,2}$ The growth in numbers of motor vehicles is a major contributing factor in developing counties. ${ }^{3}$ Injury sustained by the occupants of a motor vehicle may involve the driver, front seat or back seat passengers. Front seat passengers show characteristic lacerations and injuries to the skin and knees from dashboard impact, and injuries to the face from the wind screen. There may be crush injury to the chest with fracture of the ribs and sternum. Fracture dislocation of cervical vertebrae may also occur due to whiplash effects if the seats do not have headrests. For the backseat passengers, injury is due to striking the top or side of the vehicle or the back of the front seat. Any of the occupants may be flung out of the vehicle if the door springs open or through the windscreen area.

Use of safety equipment by passengers like seatbelt, headrest, collapsible steering or airbags may modify any of the above injuries. ${ }^{4,5}$ Uncommonly use of seat belt is occasionally associated with the following injuries; linear bruises to the bowel and mesentery, strap like abrasions over anterior aspect of the shoulder and clavicle, rarely spinal injuries. These rear occurrences should not be interpreted as valid arguments against the use of seatbelts. ${ }^{4}$

\section{Patients and Method}

Between August 2002 and July 2003, all accident cases in Benin City as far as possible were followed up especially those presenting in the two referral health centers, the Central Specialist Hospital and the University of Benin Teaching Hospital. Consent was sought for and received for this study to be done in both hospitals, including using facilities for post mortem examinations. Cooperation was also obtained from the department of the Federal Road Safety Corps in Benin-City. They in turn alerted us of all RTAs in the City, from where our study began after patients consent was duly extracted. A simple questionnaire was also administered to informants and conscious participants. Injury patterns were studied and autopsies were carried out on dead victims to ascertain the cause of death following due legal procedures. Data was then collected and analyzed using simple percentages to establish the pattern of morbidity and mortality among road users.

\section{Results}

The results are shown in Tables $1-4$. Over all, out of 283 individuals involved as recorded in the period of study, 87 were car occupants representing $30.7 \%$ of all individuals, and are composed of 67 cases of morbidity or $23.7 \%$ of all morbidity, while mortality frequency was 20 or $38.5 \%$ of all mortality (table1). Commercial Cars occupants had 76 out of 87 Cars occupants representing $87.4 \%$ of car Occupant accidents. Car occupants had the largest number of accident cases 87 (30.7\%) of all Accident categories.

Table2 shows the age and sex distribution of car occupants, in which males were 59(67.8\%) while females were $28(32.2 \%)$, with a male to female ratio of 2.1:1. Majority of the car occupants who sustained injuries were males numbering 35 (40.2\%) of car occupants, while female car occupants were 22 representing $25.3 \%$ of all.

Of the 51 cars involved in car accidents 9 drivers (17.6\%) admitted to using seat belts. Windscreen injuries 44 (50.6\%) especially facial and head lacerations as well as skull fractures in severe cases was the predominate cause of death. Steering injuries including crush injury to the 
chest with fracture of the ribs in some cases was the next most common injury, and finally multiple body injuries especially in those flung out and spinal injury in that order. Finally majority of those who died were involved in lone accidents, with intra cranial hemorrhage as the predominant cause of death (Table 3).
The post mortem findings (Table 4) show that fractured skull with intracranial hemorrhage was the predominant cause of death in 50 cases $(96.2 \%)$, with ruptured viscus and hemorrhage accounting for $3.8 \%$ of deaths.

Table 1. Morbidity and mortality among road users

\begin{tabular}{|c|c|c|c|c|c|}
\hline \multirow[t]{2}{*}{ Category of road users } & \multirow[t]{2}{*}{ No. of accidents } & \multicolumn{2}{|c|}{ Morbidity } & \multicolumn{2}{|c|}{ Mortality } \\
\hline & & No. & $\%$ & No. & $\%$ \\
\hline Pedestrians & 44 & 38 & 13.4 & 6 & 11.5 \\
\hline Motorbike (drivers/ passengers) & 51 & 45 & 15.9 & 6 & 11.5 \\
\hline Cars (drivers/passengers) & $87^{*}$ & $67^{* *}$ & 23.7 & 20 & 38.5 \\
\hline Truck/ lorry (drivers/passengers) & 21 & 10 & 3.5 & 2 & 0.39 \\
\hline Bicycles & 3 & 3 & 1.05 & - & - \\
\hline Trailers (drivers/passengers) & 8 & 4 & 1.4 & - & - \\
\hline $\begin{array}{l}\text { Bus (drivers/passengers) } \\
\text { (all commercial) }\end{array}$ & 61 & 43 & 15.2 & 18 & 34.62 \\
\hline Not specific & 8 & 8 & 2.8 & - & - \\
\hline Total & 283 & & & 52 & \\
\hline
\end{tabular}

Table 2. Age and sex distribution of road users (car occupants) involved in road traffic accidents

\begin{tabular}{lll}
\hline Age (years) & $\mathbf{M}$ & $\mathbf{F}$ \\
\hline $10-20$ & 5 & 1 \\
$21-30$ & 15 & 4 \\
$31-40$ & 25 & 12 \\
$41-50$ & 8 & 4 \\
$51-60$ & 6 & 7 \\
\hline Total & $* 59$ & $* * 28$ \\
\hline$* 35$ males sustained injuries $(40.2 \%)$. the rest escaped unhurt; ${ }^{*} 22$ females sustained injuries (25.3\%). Others were unhurt
\end{tabular}

Table 3. Causes of car accidents and predominant cause of injury seen among car occupants

\begin{tabular}{|c|c|c|c|c|c|c|c|}
\hline Cause of accident & 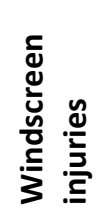 & 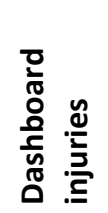 & 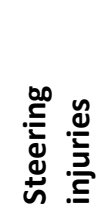 & ֻ & $\frac{\frac{0}{0}}{\frac{2}{2}} \frac{y}{\frac{0}{2}}$ & 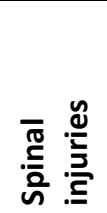 & 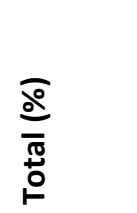 \\
\hline Struck by lorry & 2 & 2 & - & - & - & - & $4(4.6)$ \\
\hline Poor road conditions & 2 & - & 2 & - & 2 & - & $6(6.9)$ \\
\hline Struck by car & - & - & 4 & - & 1 & 2 & $7(8.0)$ \\
\hline Burst tyres & 9 & - & 8 & - & 5 & - & $22(25.3)$ \\
\hline Lone accidents & 31 & - & 14 & 1 & 1 & 1 & $48(55.2)$ \\
\hline Total & 44 & 2 & 28 & 1 & 9 & 3 & $87(100)$ \\
\hline
\end{tabular}

\section{Discussion}

The mounting toll of road traffic accidents injury deaths in Nigeria constitutes a public health problem, which requires urgent attention since these deaths are preventable.
The pattern of injuries sustained in these fatalities has received relatively little attention in Nigeria. ${ }^{6}$ In Benin- city, hospital records showed that $23 \%$ of deaths that occurred from August 2002-July 2003 was documented to be due to road traffic injuries . 
Table 4. Post mortem findings of cause of death in 52 patients

\begin{tabular}{|c|c|c|}
\hline Post mortem finding & No. & $\%$ \\
\hline \multicolumn{3}{|l|}{$\begin{array}{l}\text { Fractured skull with intracranial } \\
\text { heamorrhage }\end{array}$} \\
\hline pedestrians & 4 & 7.7 \\
\hline motor bike riders/passengers & 6 & 11.5 \\
\hline car drivers/passengers & 20 & 38.5 \\
\hline lorry drivers/passengers & 2 & 3.85 \\
\hline bus drivers/passengers & 18 & 34.6 \\
\hline $\begin{array}{l}\text { Ruptured viscera or amputation } \\
\text { with heamorrhagic shock (all } \\
\text { pedestrians) }\end{array}$ & 2 & 3.85 \\
\hline
\end{tabular}

The most common vehicle types in Nigeria are cars and it accounted for the most common category of road traffic accident morbidity and mortality. This study in Benin City showed that about $80.9 \%$ of vehicle users admitted non-usage of seat belts despite recent campaigns by the road safety corps and its enforcement in Nigeria. Similar trends were found in other parts of Nigeria, Uganda and also noted in WHO report of April $2004 .^{6-8}$ This study shows a fatality figure of $23 \%$, which is rather high, probably because of poor use of seatbelts as already seen. Over $80 \%$ of cars driven in Nigeria are used cars imported from Europe which are prone to frequent break-down. These cars are also run with a poor maintenance culture and with fairly used tires further compounding the morbidity and mortality pattern. The roads are riddled with pot holes some of which are large enough to take a whole car. Also poor traffic law enforcement agent further compounds the scenario. The average blood level of $54.16 \mathrm{mg} / \mathrm{dl}$ among the dead car drivers and passengers also means our blood alcohol monitoring among traffic offenders leave more questions than answers.

The WHO-World Bank report suggests that developing countries could improve their situations by better demarcating the roads, improving traffic management and enacting stricter vehiclestandards. ${ }^{6}$ The text also calls for stricter laws on maximum traffic speeds, campaigns to encourage seatbelt use, and the application of alcohol consumption limits for drivers. ${ }^{7}$

Commercial Cars occupants had 76 out of 87 Cars occupants representing $87.4 \%$ of car Occupant accidents apparently because they are overloaded and poorly maintained and under more pressure to speed to make more money. This is similar to the observation made by Odero who in a paper presented at a seminar hosted at Harvard center for development and studies, in April 30 2004, Wilson Odero, the Dean school of public health at Moi University Kenya asserted that about $10 \%$ of global road accident deaths occurred in sub-Saharan Africa in 1999, even though the region has about four percent of the worlds registered vehicles. One study estimated the total road traffic mortality in the region as numbering up to 82200 in $2002 .^{9}$ Odero cited a number of factors for the road mortality epidemic in Africa as speeding, alcohol and drug abuse, driver negligence, overloaded vehicles, inadequate vehicle maintenance, burst tires, bad roads, pedestrian negligence, driver fatigue and drivers' distraction while speaking on cell phones. ${ }^{9}$

Majority of the car occupants who sustained injuries were males numbering 35 or $40.2 \%$ of car occupants, while female car occupants were 22representing $25.3 \%$ of all .Mortality frequency was 3 for females and 17 for males with ratio of 1:5.7. This is due to the paternistic nature of our society a fact already noted by Eke N. ${ }^{10}$ Most involved patients were in the 15-44-year old bracket, causing depletion of our nations viable work force, with its attendant economic toll.

Windscreen injuries from above involve facial and head lacerations and others caused by the momentum of hauling tightly packed passengers against one another and other hard components of the vehicle including secondary injuries sustained by being thrown entirely out of the vehicle. Windscreen injuries especially facial and head lacerations as well as skull fractures in severe cases was the predominate cause of death in these cases, of car injuries. Steering injuries including crush injury to the chest with fracture of the ribs in some cases was the next most common injury, and multiple body injuries especially in those flung out and spinal injury in that order. Finally majority of those who died were involved in lone accidents, with intra cranial hemorrhage as the predominant cause of death.

The most common fatal injury was intracranial hemorrhage. This agrees with the findings of. Lawrence et al where the major cause of death in road accident is severe head injury. ${ }^{11}$ Generally fatal head injury did not occur in isolation but in association with skull fractures and sometimes other fractures. This is also in agreement with the findings of Azian Abdul Aziz: who also stated "generally head injury does not occur in isolation. It usually is associated either with fracture of skull and/or limbs. In a study conducted at University Sains Malaysia in 1998, it was found that approximately $50 \%$ of 103 patients with intra-cranial hemorrhage had associated skull fractures." ${ }^{12}$

Steering injuries including crush injury to the chest with fracture of the ribs in some cases was the next most common injury, and finally multiple body injuries especially in those flung out and spinal injury in that order. This would suggest that front seat passengers as well as gross neglect of the use of seat belts are significant determinants favoring this mode of injury, more so as majority of those who died were involved in lone accidents. 
In conclusion there is a high mortality rate of car occupants once they are involved in a road traffic accident because they are poorly maintained usually imported as fairly used, over sped, coupled with bad roads and use of second hand tires among drivers. This averages $77 \%$ of involved passengers. The morbidity is also high at $23 \%$ of car occupants, for the same reasons. Windscreen injuries most commonly associated with facial and head injuries represented the commonest cause of morbidity and mortality. The most common cause of death being intracranial hemorrhage, which may not occur in isolation.

\section{References}

1. Murray CJ, Lopez AD. Evidence-based health policy-lessons from the Global Burden of Disease Study. Science. 1996; 274:740-743.

2. Krug E, ed. Injury: a leading cause of global burden of disease. Geneva: WHO, 1999. www.who.int/violence_injury_prevention/index. html (accessed 18 Dec 2006).

3. Nantulya VM, Reich RM. The neglected epidemic: road traffic injuries in developing counties. BMJ. 2002; 324:1139-1141.

4. Rafindadi AH. A Handbook of Forensic Medicine. Amana Publishers Limited, Zaria. 2003: 21-27.

5. Rafindadi AH. A review of Injuries sustained following road traffic accidents and their prevention. Nigerian Journal of Surgical Research. 2000; 2:100-104.

6. Adeloye A, Odenu EL. The pattern of road traffic accidents seen at the university college hospital,
Ibadan, Nigeria. West Afr J Med. 1970; 19:153157.

7. World Health Report. World Health Day 2004 Theme: Road safety is no accident. April 7 2004:1. www.who.int/world-healthday/2004/en/newsletter nov03 en.pdf (Accessed 1 March 2007).

8. Andrews CN, Kobusingye OC, Lett R. Road traffic accident injuries in Kampala. East Afr Med J. 1999; 76:189-194.

9. Odero W. Paper titled; Road traffic injuries little discussed killer in sub-Saharan Africa. At Harvard center for population and development studies. April 9 2004:1-2.

www.unisa.ac.za/contents/faculties/humanities/ shs/docs/safety-2005vol1.pdf (Accessed 1 March 2007).

10. Eke N, Etebu EN, Nwosu SO. Road traffic mortalities in Port Harcourt, Nigeria. Anil Aggrawal's Internet. Journal of Forensic Medicine and Toxicology. 2000; 1 :( July-Dec).

http://geradts.com/anil/ii/vol 001 no $002 /$ paper006.html.

11. Marshall LF, Gautille T. The outcome of Severe closed head injury. J Neurosurg. 1991; 75:S28S36.

12. Abdul Aziz A. Computed Tomography of the brain in predicting outcome of Traumatic intracranial hemorrhage in adult patients. Dissertation submitted for the degree of Master of Medicine (Rad). 1998. www.bioline.org.br/request?mj03020 (Accessed 1-03-2007). 